\title{
Byzantine Theoretical Treatises on Music in comparison with the Theoretikon Mega tes Mousikes by Chrysanthos of Madytos
}

\section{GERDA WOLFRAM ${ }^{\star}$}

^Universität Wien, Austria. - gerdawolfram@aon.at.

Studying the Theoretikon Mega tes Mousikes one can state, that the ambition of Chrysanthos of Madytos was to preserve the old Byzantine tradition to a certain extent, but also to take into account the development of liturgical music during the last three hundred years. With the alterations in liturgical chant, music theory had to be revised and to be based on a new fundament. Above it Chrysanthos was attempting to provide a Great Theory of [All] Music, reaching beyond the confines of Orthodox ecclesiastical chant to consider the origins of music and its development in other traditions.

In Byzantine theoretical treatises there are comments of the authors on the topic of writing a draft. It is obvious that they wanted to clear up oral transmission, to formulate a secure basis for singers and melodes and to show the influence of classical Greek grammar and music theory. ${ }^{1}$ In addition to these motives there are also passages of patristic texts. ${ }^{2}$ While notated liturgical manuscripts were already handed down from the $10^{\text {th }}$ century onwards, theoretical treatises were written rather late, between the $14^{\text {th }}$ and $16^{\text {th }}$ century. Only the Hagiopolites has sections which seem to go back to the $12^{\text {th }}$ century. ${ }^{3}$

In five big sections Chrysanthos shows the substantial elements of his newly formulated theory. Beyond it he also incorporates essential elements of the old theoretical treatises to make evident the relation between the two traditions. Chrysanthos must have studied above all Gabriel Hieromonachos, the Hagiopolites, Manuel Chrysaphes and the compendium of ten different treatises, called Pseudo-loannes Damaskenos, partly depending on the Hagiopolites, the tradition of Jerusalem.

Chrysanthos surpasses Byzantine authors of treatises of music theory in his frequent quotation of

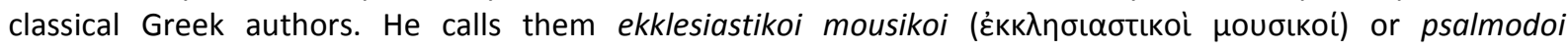
( $\psi \alpha \lambda \mu \omega \delta \circ i)$. This term points out on the one side the Byzantine authors of the treatises, on the other side the melodes, i.e. the composers, and the chanters, called psaltai ( $\psi \alpha \dot{\alpha} \lambda \tau \alpha)$. Gabriel Hieromonachos calls his predecessors "oi archaioi", a term which is already used by Porphyrios and Aristeides Quintilianos. ${ }^{4}$

Chrysanthos begins his theoretical treatise with "Music is the science of melos and the occurrences round the melos" ${ }^{\prime 5}$ by Aristeides Quintilianos. Gabriel Hieromonachos defines the Psaltike, the liturgical music, as follows: "Psaltike is the science, caused by rhythms and mele of the divine hymns". ${ }^{6}$ This formulation comes close to the Excerpta Neapolitana": "Music is the science of rhythm and melos and of the whole musical theory".

For both traditions the dia pason ( $\delta \grave{\alpha} \alpha \alpha \sigma \omega \tilde{v}$ ), the seven chords of the organon, corresponding to the seven intervals of the octave, are decisive for the eight echoi of liturgical music. Dia pason is also called

\footnotetext{
${ }^{1}$ Conomos, Dimitri E., ed. The Treatise of Manuel Chrysaphes, the Lampadarios, CSRM 2 (MMB), (Vienna: Verlag der Österreichischen Akademie der Wissenschaften, 1985), 37; Hannick, Christian - Wolfram, Gerda, edd., Gabriel Hieromonachos, Abhandlung über den Kirchengesang, CSRM 1 (Vienna: Verlag der Österreichischen Akademie der Wissenschaften, 1985), p. 37; Wolfram, Gerda - Hannick, Christian, edd., Die Erotapokriseis des Pseudo-Johannes Damaskenos zum Kirchengesang, CSRM 5 (Vienna: Österreichische Akademie der Wissenschaften, 1997), p. 29; Wolfram, Gerda, Akakios Chalkeopulos, CSRM 6 (Turnhout: Brepols, 2021), p. 58.

${ }^{2}$ Wolfram - Hannick, Pseudo-Johannes Damaskenos, lines 99-125.

${ }^{3}$ Raasted, Jørgen, The Hagiopolites, A Byzantine Treatise on Musical Theory. Preliminary Edition. Cahiers de I'Institut du Moyen-Âge Grec et Latin 45 (1983). Parts of the treatise reflect various stages of musical notation within Byzantine musical theory (§§ 1-55); the rest consists of Ancient Greek musical theory, most of Anonymus Bellermanni, 3.

${ }^{4}$ Hannick - Wolfram, Gabriel Hieromonachos, p. 118.135.

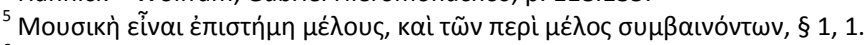

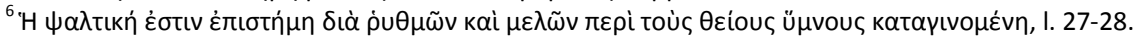

${ }^{7}$ Janus, Carolus, Musici Scriptores Graeci, (Hildesheim, 1962), p. 412,17; Hannick - Wolfram, Gabriel Hieromonachos, p. 110,27.
} 
diplophonia or diplasmos ${ }^{8}$ by the Byzantine theorists. Gabriel Hieromonachos writes that in Byzantine music the ambitus of a melody never exceeds dis dia pason ( $\delta i \varsigma \zeta \delta \dot{\alpha} \pi \alpha \sigma \tilde{\omega} v$ ). It happens by two octaves with fifteen perceptible intervals, which form the analogy of dis dia pason. Therefore, the musical signs also became fifteen. ${ }^{9}$ This argument has not any relation to the system of the dis dia pason, because it means that each interval of the two octaves belongs to a certain musical sign. Rather the fundamental tones of the eight echoi lie in two separated tetrachords, extended by a conjunct fourth below and above. The echoi kyrioi, the authentic modes, have their initial tone in the higher tetrachord of the central octave, from $a$ to $d$, the plagal echoi have their initial tone in the lower tetrachord from D to G. Following Eukleid Chrysanthos speaks of an

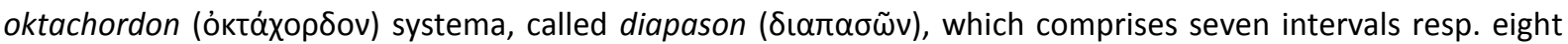
chords, i.e. tonoi (tóvol). ${ }^{10}$ He introduces the eight letters $\pi \alpha$ bou $\gamma \alpha \delta \iota \kappa \varepsilon \zeta \omega v \eta \pi \alpha$ for the octave $D$ to $d$. The comparative edition of the Great Theory of Georgios Konstantinou is a useful resource of Chrysanthos' opus. ${ }^{11}$

In Byzantine theory there are two terms for interval (diastema): In the Hagiopolitan tradition tonos, in the later tradition tonos or phone ( $\phi \omega v \eta \dot{)}$. Phone can also be a tone or the voice. The term diastema for interval does not exist in the Byzantine theoretical treatises. Only the Hagiopolites, in the part of the Anonymus

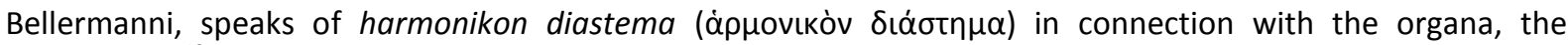
instruments. ${ }^{12}$

Apart from diapason, the oktachordon systema, Chrysanthos speaks also of pentachordon and tetrachordon systema. Pentachordon shows the system of the trochos, the wheel, which moves the diastematic intervals of the modes in fifths upwards and downwards. ${ }^{13}$ Decisive for this movement in Byzantine music are the intonation formulas, the so called apechemata ( $\dot{\alpha} \pi \eta x \eta \dot{n} \mu \tau \alpha$ ) or enechemata, of the eight modes,

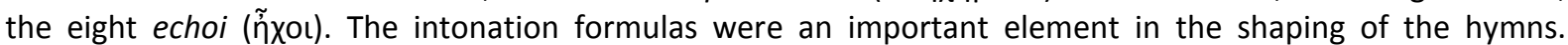
Already in adiastematic notation from the $11^{\text {th }} / 12^{\text {th }}$ century there are notated martyriai ( $\mu \alpha \rho$ tupial), modal signatures, which are abbreviations of the apechemata of the echoi. These intonation formulas were also sung within a hymn to show a modal transition or to show the right height to the chanters. In kalophonic music, the highly ornamented singing, from the first half of the $13^{\text {th }}$ century and thereon, are long intonation formulas, partly with meaningless syllables at the beginning of the compositions, but also within the melodies. Apechemata are on the one side elements to structure a certain echos, on the other side they are a highly aesthetic element in Byzantine composition. The pentachordal system came into use from $13^{\text {th }}$ century onwards. The kalophonic compositions moved within two octaves, also within the pentachordon and the tetrachordon systema, the tetraphonia and the triphonia. The mele of the oldest liturgical hymns of the Sticheraria and Heirmologia are within an octave. Numerous diagrams of kanonia and wheels in Byzantine manuscripts hand down these systems. ${ }^{14}$ The most famous is the trochos of John Kukuzeles.

By means of the Byzantine martyriai and apechemata Chrysanthos shows very detailed how to move within the trochos and the triphonia. In a diagram he shows a klimax ( $\mathrm{\lambda}(\tilde{\mathrm{c}} \mu \alpha \xi)$ with the martyriai of the trochos in the diatonic genos, on the opposite the martyriai of diapason, also in the diatonic genos. He shows the eight echoi of the psalmodoi, the Byzantine melodes, and quotes Manuel Chrysaphes, how to find a certain echos. For the first time the legetos, the mesos of the fourth mode, is mentioned. In late Byzantine musical manuscripts there are compositions in the legetos, the diatonic echos of the second mode, but few references to it in the theoretical treatises. ${ }^{15}$ In all Byzantine treatises you cannot find any statement of the exact size of a pitch. In contrary to the reformed music theory of Chrysanthos, where the pitch of each note is fixed by the kanonion, whereas in Byzantine diastematic notation the pitch of each note is defined by a numeric description of the interval distance of the note immediately preceding.

\footnotetext{
${ }^{8}$ Diplophonia resp. diplasmos can also mean simultaneous chanting one octave higher or lower. See Wolfram - Hannick, Pseudo-Johannes Damaskenos, p.147, 750.

${ }^{9}$ Hannick - Wolfram, Gabriel Hieromonachos, lines 129-34.

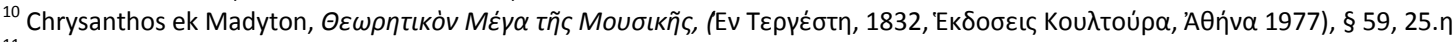

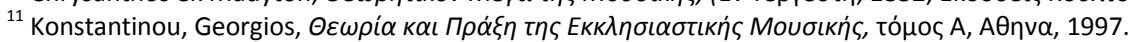

${ }^{12}$ Raasted, The Hagiopolites, § 96, line 1.

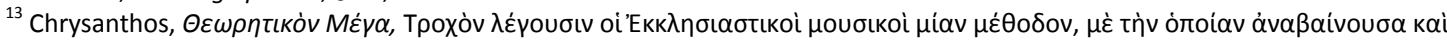

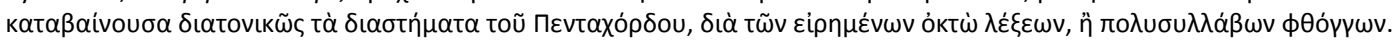

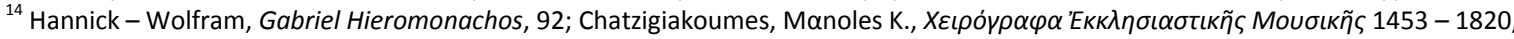

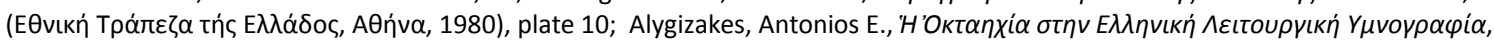

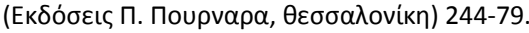

${ }^{15}$ Alygizakes, 'H Oктапхі́⿱一⿻上丨, 239, 22.
} 


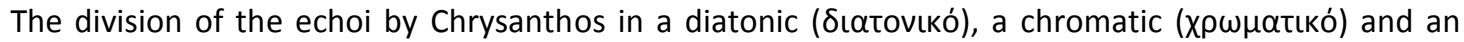

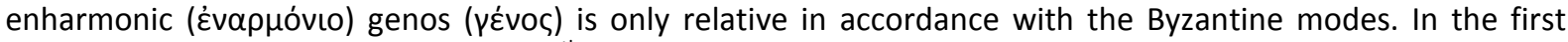
records of Byzantine hymns in the $10^{\text {th }}$ century, we find symbols of the phthorai nana and nenano. Nana indicates the modulation into its triphonos $G-c$. Nenano is more complex. It shows chromatic alterations in different tonal areas and always ends in the second plagal mode. On the basis of Byzantine theoretical treatises and musical examples we can assume for the Nenano a chromatic tetrachord of $e f$ gis $a$ resp. $d$ es fis $g .^{16}$ There are some instances where Nenano appears diatonic up through the thirteenth century, especially heirmoi of the plagal second mode with frequent use of the ascending fourths $D-G(p a-d i)$ and $G-C(d i-n i)$.

Relating to the idea of the echoi there are only few clear statements of the Byzantine authors. Gabriel Hieromonachos says each mode has its own perceptible tone colour, which discerns it from the other modes. He speaks of echos protos, which has the most features of all the modes. It has the medium tone colour, the tetraphonos and the so-called naos. Its idea appears in each echos like a certain chroma, a colour. ${ }^{17}$ 'In the eight echoi the whole melodic repertoire can be found, as well as in instrumental music as in vocal music both of the barbaric and the Hellenic' ${ }^{18}$ There is not a certain scale which forms every single echos, but decisive are the formulaic melodic constructions. From this, Troelsgård concludes, that 'The criterion for ascribing a given echos to a particular melody seems to have been not so much a specific scale structure observed throughout the piece as the application of a specific set of melodic formulas, considered to belong to one mode in one of the chant genres'. ${ }^{19}$

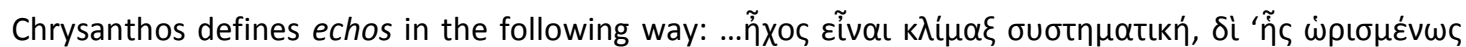

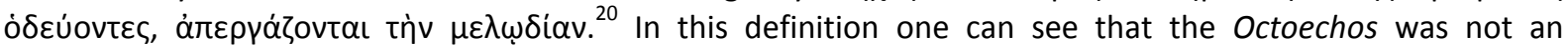
inflexible system, but was improved and adapted to the new repertoire in the course of the centuries.

For Chrysanthos composing and chanting on a high level was important. He speaks like the Byzantine

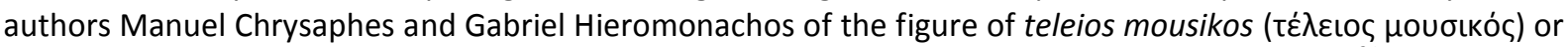

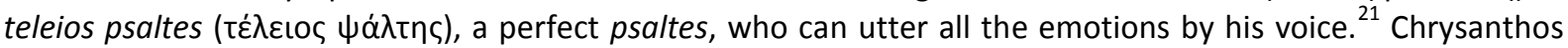
distinguishes between melos, which is called teleion and melodia which is imperfect. Only the combination of melody, rhythm and words results in the sacred melos, called psalmody. ${ }^{22}$

Several times Chrysanthos emphasizes that a perfect melodos, a composer, has to create mele ( $\left.\mu \varepsilon^{\lambda} \eta\right)$ which please the audience. ${ }^{23}$

Which skills were expected of an excellent singer (a 'teleion' psaltes) of Byzantine music? Gabriel Hieromonachos informs us that a psaltes should:

1. Have command of the artistic skill of the orthography of chant;

2. Sing from music, that means from notated manuscripts;

3. Write down from memory all melodies he knows;

4. Compose chants;

5. Be able to understand and notate any melody he hears;

6. Eventually write down a melody from cheironomy provided he gets to know the mode.

\footnotetext{
${ }^{16}$ Wolfram, Gerda, "Die Phthorai der paläobyzantinischen Notationen“, in: Palaeobyzantine Notations. A Reconsideration of the Source Material, Raasted, Jørgen - Troelsgård, Christian, edd., Hernen, 1995, 119-29; Zannos, loannis, Ichos und Makam. Vergleichende Untersuchungen zum Tonsystem der griechisch-orthodoxen Kirchenmusik und der türkischen Kunstmusik. (Bonn, Orpheus Verlag, 1994), 112.

${ }^{17}$ Hannick - Wolfram, Gabriel Hieromonachos, lines $424-45$.

${ }^{18}$ Hannick - Wolfram, Gabriel Hieromonachos, lines 534-36.

${ }^{19}$ Troelsgård, Christian, Byzantine Neumes. A New Introduction to the Middle Byzantine Musical Notation (MMB 9), Copenhagen, 2011, 61.2

${ }^{20}$ Chrysanthos, $\Theta \varepsilon \omega \rho \eta \tau \iota k o ̀ v ~ M \varepsilon ́ \gamma \alpha, \S 281,124$. 'Echos is a systematic klimax, by which definitely proceeding, they (musicians) beget the melody.'

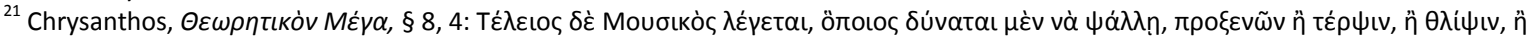

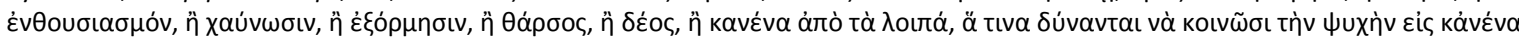

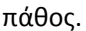

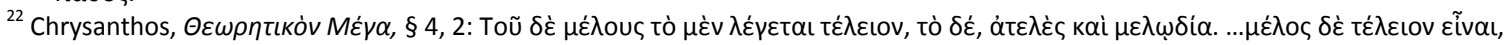

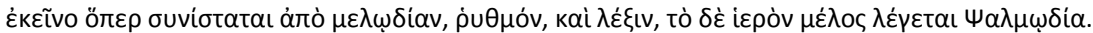

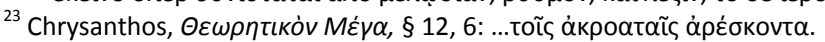


At the end of his list, Gabriel states that the beautiful and melodious chanting with artistic skill is more a gift of nature than of training. ${ }^{24}$

Manuel Chrysaphes gives his special attention to the art of composing. He too mentions six categories, which define a 'teleion' psaltes, but primarily in combination with the knowledge of composition. Such a psaltes should have the ability:

1 To compose appropriate and fitting theseis (melodic formulas) following the rules of the art of chanting;

2 Not to follow slavishly and copy from the book, but to write with certainty without the book and as required by the art, whenever a composition is requested;

3 To sing at sight every kind of lesson, old and new, flawlessly, at any time and on every occasion, without the previous study or thought;

4 To write and to chant exactly the melody that another singer performs;

5 To compose all kinds of original pieces either from one's own initiative or from an outside commission both with and without preparation. ${ }^{25}$

6 The last skill regards the judging of the compositions. This is partly the ability to judge what is good and accurate in the work and what is not, and partly to recognize someone's work simply by hearing it. According to Manuel Chrysaphes, this is indeed the greatest achievement of all in the art of chanting.

Chrysanthos speaks of the ekklesiastikoi mousikoi, who chanted and composed the different kinds of psalmody, creating rhythms, which they performed by cheironomy, and found mele, tuned to the essential. ${ }^{26}$

The art of cheironomy was probably not still in use in late Byzantine times. In the course of the centuries, the practice to conduct the choirs by cheironomic signs got lost. There are only few records of this technique. The late authors make mention of Kosmas of Jerusalem and John of Damaskus who invented these signs. ${ }^{27}$ The cheironomic signs, well-known by the Mega Ison of John Kukuzeles, where each sign is sung by its own name, became an essential element in the late repertoire of kalophonic chants. Long melismata, ornamental performances, chants with meaningless syllables, were structured by the cheironomic signs and were the expression of high musical culture of Byzantine chant. ${ }^{28}$

As one can understand by selected examples from Byzantine and Chrysanthine music, through all the centuries ecclesiastical chant was in a state of flux and could all the time be adapted to new musical styles. The oldest references to modally ascribed chants appear in Papyros fragments from the $6^{\text {th }} / 7^{\text {th }}$ century. ${ }^{29}$ Predominant at these centuries was the Palestinian tradition, which influenced in a great extent the tradition of Constantinople. With the formation of the first Palaeobyzantine Notation the liturgical books of the Sticheraria and the Heirmologia became available. The further development to the diastematic Middle Byzantine Notation, from the middle of the $12^{\text {th }}$ century onwards, gave the precondition of the enlargement of a continuous expanding repertoire. The new kalophonic compositions of John Kukuzeles, Xenos Korones and many others, later on Manuel Chrysaphes, formed a transition to the compositions of Germanos Neon Patron, Chrysaphes o Neos and Balasios in the $18^{\text {th }}$ century. They show how music developed further with the modal structure of the echoi in use, with the semeiography of this time. In the $19^{\text {th }}$ century, the musical creations of Petros Peloponnesios became the most important repertoire. Countless transcriptions of chants into the New Method by Chourmouzios Chartophylax and Gregorios Protopsaltes made accessible the melodies of the preceded

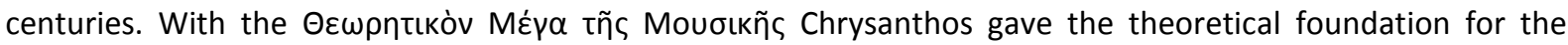
musical reform.

\footnotetext{
${ }^{24}$ Hannick - Wolfram, Gabriel Hieromonachos, 101.

${ }^{25}$ Conomos, Manuel Chrysaphes, 47.

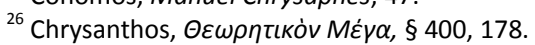

${ }^{27}$ Wolfram - Hannick, Pseudo-Johannes Damaskenos, lines 530-33: 'Cheironomy is a traditional law, handed down by St Kosmas, the poet and by St John of Damaskus. As soon as the voice of the singer sounds, the cheironomy comes in to show the melos'.

${ }^{28}$ An extensive treatise about cheironomic signs is the dissertation of Maria Alexandru. See: Alexandru, Maria, Studie über die 'großen Zeichen' der byzantinischen musikalischen Notation, unter besonderer Berücksichtigung der Periode vom Ende des 12. bis Anfang des 19. Jahrhunders, 3 vols (Ph. D. Diss., Univ. Kopenhagen, 2000).

${ }^{29}$ One of these examples is Vind. G. 26.189, and Sinai gr. 212, a Melkite lectionary from the $7^{\text {th }} / 8^{\text {th }}$ century, which shows a list of the eight modes, s. Troelsgård, Byzantine Neumes, 60, 167.
} 